\title{
Between the fairy tale and the abyss: the creation of a Supreme Court for the United Kingdom?
}

\author{
Derek Morgan \\ Cardiff Law School
}

\author{
'... at every moment of our lives, we all have one foot in a fairy tale and \\ the other in the abyss ...'1
}

We live in what Brian Simpson reminds us has been called the age of rights. ${ }^{2}$ These 'rights' are now often expressed, formally, in some definitive constitutional document. These rights and those documents pose special problems and afford particular opportunities for courts with final appellate authority. Taken together, the essays that are gathered in this special issue of Legal Studies constitute an examination of the authority, accountability and independence of the judges of a final appellate court, the Supreme Court proposed for the United Kingdom in Consultation Papers issued by the United Kingdom Government in June 2003. The importance of these issues may be thought to be self-evident in mature democracies, even where those democracies are themselves in flux, even if there is no simple or fixed core, let alone penumbra, to the concepts of authority, accountability and independence themselves. Alternatively, a reason for engagement with the issues can be readily ascertained, as Tracey Stevens and George Williams remind us, from the statement of Lord Porter in Commonwealth $v$ Bank of $N S W^{3}$ on appeal from the High Court of Australia: 'The problem to be solved [by the final court] will often be not so much legal as political, social or economic. Yet it must be solved by a court of law.'

The intellectual origins of the United Kingdom Supreme Court, were it to come into being, are traced and examined here, particularly in the essays of Robert Stevens, Kate Malleson, Diana Woodhouse, Thomas Legg and Andrew Le Sueur. And, as Richard Cornes shows, many of the concerns about the 'politicisation' of judicial decision making in a transition to a Supreme Court were mirrored in the debate about the establishment of a New Zealand Supreme Court to replace appeals to the Privy Council from that jurisdiction. That Court began its work on 1 January 2004.

The constitutional changes foreshadowed in the Consultation Papers are likely to be a continuing, developing colloquy. If enacted, and at least half of the current judicial members of the House of Lords have indicated their

1. Paulo Coelho Eleven Minutes (Sydney: HarperCollins, 2003) p 1.

2. A W B Simpson Human Rights and the End of Empire: Britain and the Genesis of the European Convention (Oxford: Oxford University Press, 2001) p 9, citing Louis Henkin The Age of Rights (New York: Columbia University Press, 1990).

3. Commonwealth v Bank of NSW (1949) 79 CLR 497 at 639. 


\section{vi Legal Studies}

preference for something closer to the maintenance of the status quo, they might well produce a period of unsettlement or disturbance; if the critics, whose voices are well represented here, prevail, nothing. Nevertheless, these essays collectively ask not just what modern judges do and how they do it (and as John Bell proposes, whether they should continue to do exclusively the same sorts of things), various of the essays, most notably those by Thomas Legg and Judith Resnik, ask 'who should judges be?' And, implicitly, and in places explicitly, they ask what legislators and executives do in those democracies when subjected to an enhanced judicial scrutiny offered by fundamental principles, such as those enunciated in the European Convention on Human Rights. Several contributors remind us, whatever the formalist position, that the reality - as Robert Stevens describes it - is that the European Community Act 1972 and the Human Rights Act 1998 'have imposed a form of fundamental law well known to American and German lawyers'. The place of the United Kingdom in Europe suggests the value of comparison not just within the families of the common law but with continental European cousins too, as here offered by John Bell and Carlo Guarnieri, in their examinations of several Continental European Supreme Courts, and some of their appointments and career development processes.

Reflection on proposed reforms of the House of Lords in its judicial capacity engages with debates about the changing character of the United Kingdom constitution, the growth of a new sense of 'constitutionalism' and, as Brenda Hale (in an essay written before announcement of her judicial elevation to the House of Lords) puts it, the accessibility and accountability of a final court. Several of the essays argue that the proposed reforms of the judicial branch of government are, in fact, part of an evolutionary process towards a constitutionally limited form of government. Diana Woodhouse concludes her paper by alerting to a further diminution of parliamentary sovereignty. Hugh Corder, Tracey Stevens and George Williams, Andrew Le Sueur, Judith Resnik and Jeremy Webber are amongst those to take up this analysis in their contributions. But as Webber and Resnik separately identify, the notion of independence is 'confused and ambiguous' (Webber), an 'artifact of culture as much as of text' subject to new and emergent challenges in an era of judicial managerialism (Resnik).

The Consultation Papers from the Department for Constitutional Affairs have something of the character of Richard III reforms about them: 'deform'd, unfinish'd, sent before [their] time into this breathing world scarce half made up.' Indeed, it is remarkable how many of the contributing authors here sound notes of caution about the underlying reasons for the presently proposed reforms and the possible implications of implementing them, or, at the very least, of implementing them for the reasons stated. But they do not share a common judgment on the approach of the consultation process, some hailing it as 'principled', others as 'pragmatic ... constitutional reform by way of incremental change', as John Bell characterises it. Many do, however, share an exasperation with the limited and partial nature of some of the present proposals (Allan Hutchinson castigates them as 'tepid', Brenda Hale ponders whether the present modest proposals justify the consequent upheaval) and a concern that the Papers have not addressed, let alone explored, many of the issues that the establishment of a Supreme Court would entail. Others see in them the glimmerings of a more principled approach to reform than, it is said, 
has hitherto been the case with the British constitution. Several pick up on those incomplete themes or problems in the current set of proposals, and examine the means and mechanisms that might be necessary or available to reform the nature or base from which judicial appointments are made and the measures necessary for ensuring public confidence and ensuring accountability in the resulting sets of arrangements. But the comparative essays also suggest that there may be dangers ahead as a significant part of these, indeed perhaps any, reform.

Yet most of the papers share an essential optimism about the processes and values of judging in modern liberal, democratic, pluralistic society. Allan Hutchinson introduces a characteristically sceptical note about the nature of modern adjudication, which he offers as an inherently political activity, a necessary and desirable part of the political process. He advocates recognition, long denied in liberal legal formalism, that what judges do is political, not in the partisan sense, which seems universally to be feared, but in a deeply ideological, indeed philosophical, sense. Thus, easily to approbate judges for taking or making political decisions, for overriding the apparent will of elected representatives, is entirely to miss the point; what courts do, Allan Hutchinson argues, is an inescapably political engagement because, without that, a Western liberal democracy would be poorly served by its Supreme Court. Evidently, this brings dangers for that Court; Diana Woodhouse suggests that ministerial displeasure at judicial decisions is likely to increase with the creation of a Supreme Court. This view is confirmed by Tracey Stevens and George Williams in their examination of the High Court of Australia, illustrating not only the importance of independence in the institutional design of a Supreme Court, but also the need to recognise the potential for politicisation of that Court and its judges. Like the Australian High Court more recently, an independent Supreme Court with a clear human rights mandate could be vulnerable to attack by Ministers, Parliamentarians and the media. They offer practical observations on managing this tension. But, how the judiciary can and should fulfil its legitimate responsibilities in a way which as Allan Hutchinson puts it, 'vigorously enforces contested constitutional dictates as a matter of law against the legislative and/or executive branches of government, but which accepts that it is a body of unelected and unrepresentative bureaucrats which has no direct mandate to make political decisions' is the key constitutional question for the judiciary.

But it would be a mistake to imagine that the Consultation Papers constitute nothing more than reforms of antiquated parts of the judicial system. As Jeremy Webber and Kate Malleson show, they sit as part of the continuing project of a new sense of constitutionalism - a 'new vision' of the separation of powers, Malleson calls it - which have not come unheralded onto the constitutional stage. Chris Himsworth and Alan Paterson illustrate how this new vision is played out in front of a remarkably different audience in Scotland compared with England and Wales, or even, arguably, Northern Ireland. In Scotland, there are many who are looking for a different play, let alone a new production of an established classic, and the questions that the Consultation Papers do not ask of that jurisdiction represent some of the most fundamental challenges for continued constitutional stability between the south and the "Northern Kingdom'. And even those that are broached leave many doubts; how will the Court be composed, to what extent will it operate essentially as a Constitutional 


\section{viii Legal Studies}

Court (a question that also concerns John Bell), and to what extent should the revised Scottish judicial appointments system offer a model for a Court with the larger jurisdiction?

The late Christopher Hill, in his remarkable, elegant book The Intellectual Origins of the English Revolution, ${ }^{4}$ wrote that those living through a revolution were often unable to understand the experience of it; that it falls, only later, to the intellectual historians of the period, to examine the place and significance of such people, practices, papers and politics. It can hardly be thought that the Consultation Papers that this special issue records and reflects upon stand alone or apart from the more general concerns that affect or effect the modern constitutional settlement. The present proposals for establishing a Supreme Court in the United Kingdom, for making judges more accountable and for changing the nature of judicial appointments processes at least in part to mould a more socially representative judiciary, continue the task of melding human rights aspirations and the common law in the age of statutes, as Guido Calabresi once called our present legal age..$^{5}$ That statutes rather than judge-made law is now the paradigm form of law making entails a tension between judges, charged with the application of fundamental principles to those laws, and elected members of a Parliament.

Over 30 years ago, the predecessor version of this journal published an address by Lord Reid called 'The Judge as Lawmaker'. In that celebrated essay he wrote:

'There was a time when it was thought almost indecent to suggest that judges make law - they only declare it. Those with a taste for fairy tales seem to have thought that in some Aladdin's cave there is hidden the Common Law in all its splendour and that on a judge's appointment there descends on him knowledge of the magic words Open Sesame. Bad decisions are given when the judge has muddled the pass word and the wrong door opens. But we do not believe in fairy tales any more. So we must accept the fact that for better or worse judges do make law, and tackle the question how do they approach their task and how they should approach it.'6

The essays in this volume variously explore the maintenance of the constitutional love affair with the rule of law, the independence of the judiciary and its political neutrality, on the one hand, and the necessary, flirtatious involvement with political engagement on the other. There is, thus, much in these essays of what the modern judicial task properly comprises. Collectively, they review the proposed new constitutional arrangements for walking between the fairy tale and some real or imagined democratic abyss.

This special issue of Legal Studies was conceived in the weekend after the Government's announcement of a reform consultation process in June 2003. The papers were gradually commissioned thereafter, sometimes in something like Old Testament fashion: A begat B; B begat C; and so on. The authors have worked against a formidable editorial deadline (in one case of no more

4. (Oxford: Clarendon Press, 1965).

5. A Common Law for the Age of Statutes (Cambridge, Mass: Harvard University Press, 1982).

6. (1972-73) 12 Journal of the Society of Public Teachers of Law 22. 
than two weeks), but with little editorial mandate, to produce papers that, I hoped, would contribute to the debate as much as be a reflection upon it. There are evident omissions: I failed to commission a paper from India, which, as Justice Michael Kirby of the High Court of Australia reminded us in his recently delivered Hamlyn lectures, has one of the most fascinating of Supreme Courts, and I was unable to contact authors whom I should have liked to reflect on recent constitutional changes in the Caribbean. Nonetheless, I am especially grateful to each author who responded to the task, and for the enthusiastic way in which they approached their essays, often putting aside current work to draft their contribution. To the copy editors and typesetters, Juliet and Jonathan Doyle, I owe a special note of appreciation for dealing with this issue of Legal Studies with their customary professionalism tempered, on this occasion, with lightning speed. I am delighted to be able to record an appreciation of the work that they do for this journal, and this is an appropriate occasion on which to do it. 